\title{
THE ROLE OF THE GOVERNMENT AS A PARTICIPANT IN THE INNOVATIVE AGRICULTURE SYSTEM
}

\author{
Gohar Voskanyan \\ Ph.D. in economics, Scientific researcher \\ M. Kotanyan Institute of Economics of the NAS RA, Yerevan, Republic of Armenia
}

DOI: https://doi.org/10.31435/rsglobal_conf/30112020/7266

\begin{abstract}
Innovation is considered to be the driving force of the whole economy, as well as the development tool of the agrarian sector in particular. Innovation enables us to overcome both local and global challenges. The article presents the innovative capacity in agriculture, models, participants, etc. The main directions of governments' activities in the field of innovation in different countries and the tools with which the governments try to promote innovative development have been studied. Agriculture is one of the most important sectors of the Armenian economy, in which there are many unresolved issues. The best and the most effective way to solve these problems is through innovation. However, the studies show that the process of innovative development of the RA agrarian sphere is very slow, which is partly due to the shortcomings in the field of science. The article presents some indicators of RA science. The conclusion section of the article presents clear recommendations that should be implemented by the RA Government to increase the efficiency and competitiveness of the agricultural sector through innovation.
\end{abstract}

Keywords: agriculture, innovation, government, development, science

Introduction. Innovation is the driving force behind economic development. There are different views on the definition of innovation. In general, innovation is considered a technologybased process, which, using new approaches, increases productivity, competitiveness, people's incomes and improves the living standards of the population. Innovation is a complex process where multiple actors play different roles. Governments and other key stakeholders, including civil society, farmer organizations, research bodies and the private sector, all have a role to play in creating an environment that enables innovation in agriculture to flourish and generate solutions. Success hinges on connecting the drivers that influence innovation uptake ${ }^{1}$.

Purpose of the research. One of the most important actors of agricultural innovation systems is government. In most countries, governments provide strategic guidance for research and innovation, and provide funding to research institutions, private companies, and advisory systems. Government funding can be granted directly to research institutions, or through funding organizations, such as research councils or foundations, which allocate funds to projects. Depending on the country, part or all of agricultural research funding is integrated into the general innovation policy. In several countries, the Ministry in charge of agriculture plays a prominent role in funding and performing agricultural research via agricultural research institutes that are part or under the umbrella of the ministry (e.g. INTA in Argentina, Embrapa in Brazil, Agriculture and Agri-Food Canada's research centers, Corpoica in Colombia, and the USDA Agricultural Research Service). These research institutes include regional offices and laboratories throughout the country, and are often active in knowledge diffusion. Beside government research centers, universities in these countries also perform agricultural research and development (R\&D), and have a significant role as in the case of land-grant universities the United States. They often focus their activities on regional agricultural strengths, and receive both federal and regional funds. In the reviewed EU countries, agricultural R\&D is funded as part of general R\&D mechanisms, but performed mainly in universities with strong specialization in agriculture or life sciences (University of Life Sciences in Estonia, Latvia University of Life Science and Technologies, Wageningen University in the Netherlands, and the University of Agricultural Science in Sweden). In Estonia, Latvia and the Netherlands, the agricultural university includes

\footnotetext{
${ }^{1}$ FAO's work on agricultural innovation, Sowing the seeds of transformation to achieve the SDGs, FAO, 2018, 20 p., p. 6
} 
applied research institutes (e.g. Wageningen Economic Research). In Turkey, 43 universities are engaged in agricultural R\&D, as well as two of the TÜBITAK institutes. Diversity is even higher among advisory systems, from competitive ones with a large range of suppliers for farmers to choose from, and minor government involvement, like in the Netherlands, to comprehensive government managed and funded systems like in Korea. In Brazil, the public advisory system focuses on noncommercial, smaller farmers. ${ }^{1}$ The Inter-American Institute for Cooperation on Agriculture (IICA), as the specialized agency for agriculture and rural well-being in the Inter-American System, promotes technological and organizational innovation, taking a systemic approach to improve competitiveness, boost production and help improve the functioning of agricultural markets ${ }^{2}$.

Taking into account the importance and significance of agriculture, the Government of the Republic of Armenia is trying to work actively for the development of the sector. However, taking into account the existing problems in the RA agriculture (high levels of poverty, underdeveloped infrastructures, imperfections in the irrigation and agricultural risk management systems, small plots of land, old, worn-out agricultural machinery and so on), it can be stated that the work carried out by the government is not very effective. The aim of the research is to present clear proposals on what the RA Government should do for the development of innovative agriculture.

Methodology. Two schools of thought are prominent in the field of innovation support for agricultural or rural development. The first believes in facilitation, which aims to create conditions that are conducive to innovation. The second focuses on strategic management, which involves bringing out and supervising a community of innovating actors, called innovation community, by providing support that is gradually adapted to each phase, starting from the phases for ideation and design to those for deployment and dissemination. With more encompassing approaches being required, the discourse among researchers and development agencies gave rise to two new frameworks of thought: AKIS (Agricultural Knowledge and Information Systems) and AIS (Agricultural Innovation Systems). In both these frameworks, the interactive innovation model contrasts with the linear model. Innovation is thought of as a collective process of creation in which collective learning phenomena play a central role. The farmer is no longer relegated to the role of a mere user, one who simply adopts innovation, but becomes a full actor in innovation in his own right, as a source of knowledge and a co-designer. The AKIS framework focuses on the exchange of knowledge and information to sustain the innovation process. It is the actors of research and development, education, and agricultural advice who are at the heart of mechanisms for providing support to farmers. Participatory research methods involving farmers then followed, such as participatory research and development, participatory technology development, the Farmer First approach, or mechanisms for action research in partnership. The AIS approach is intended to be even more inclusive; it takes into account all the actors who participate, directly or indirectly, in innovation processes (input suppliers, actors of supply chains, banks, policymakers, etc.). Participation, the co-creation of knowledge and value, as well as the facilitation of actor networks become the key principles for designing new mechanisms to accompany and support innovation. The main form of operationalization of this approach is the innovation platform. Its goal is to help different categories of actors - who usually have no connection with each other - interact to share knowledge and to pool resources for innovation. Facilitation is defined as a voluntary intervention to strengthen the interactions between individuals, organizations and their social, cultural and political structures through a process of network building, social learning and negotiation. ${ }^{3}$

It is also clear that capacity building is key for knowledge management, and that cooperation in the countries should be oriented toward making every innovation system more dynamic. Knowledge is thus understood to originate from a diversity of sources: research centers (including NARIs, universities, private institutions, NGOs, international centers and others), extension systems, the know-how of farmers themselves, or a combination of all these. The approach for achieving this vision will be to create internal and external conditions that facilitate innovation in agriculture. Such

\footnotetext{
${ }^{1}$ Innovation, Productivity and Sustainability in Food and Agriculture, Main Findings from Country Reviews and Policy Lessons, OECD Publishing, Paris, 2019, p. 85,

${ }^{2}$ Innovation in agriculture: a key process for sustainable development, San Jose, May 2014, 20p., p. 1-2

${ }^{3}$ Guy Faure, Yuna Chiffoleau, Frédéric Goulet, Ludovic Temple and Jean-Marc Touzard, Innovation and development in agricultural and food systems, France, 2018, p.108-110
} 
conditions could include, for example, fostering and gaining access to knowledge and new technologies, and strengthening the capacities of private and public stakeholders to generate innovation processes in the agricultural sector. ${ }^{1}$

It has already been mentioned that the basis of innovation is science. The main indicators characterizing the field of science in the Republic of Armenia are presented in Table 1.

Table1. The main indicators characterizing the field of science in the Republic of Armenia, 2018*

\begin{tabular}{|l|c|}
\hline Indicator & Amount \\
\hline Domestic costs for research and development (mln. drams) & 10532.2 \\
\hline Number of organizations engaged in research and development, & 63 \\
\hline $\begin{array}{l}\text { Number of employees of organizations engaged in scientific researches and developments, } \\
\text { persons }\end{array}$ & 4452 \\
\hline Volume of scientific and technical works, total, (mln. drams) & 10871.3 \\
\hline
\end{tabular}

* The table was compiled by the author based on the data of the RA National Statistical Service

In 2018 the domestic costs for research and development were $10532,2 \mathrm{mln}$. drams $(0,19 \%$ of GDP). There were 63 organizations engaged in research and development. Research institutions and enterprises engaged in research activities include research institutes, design and prospecting organizations, pilot production plants not serving any outside entities, higher education institutions, scientific and technical units of industrial enterprises engaged in research, design and technological work, and also other organizations reporting R\&D activities in the period covered by their reports. The number of employees of organizations engaged in scientific researches and developments was 4452 $(0,44 \%$ of total employed people) .

Research results. Studies show that the financial support provided by the Government of the Republic of Armenia in the field of science is very small both in comparison with the leading countries of the world and in comparison with most of its neighbors. The World Bank analyzed the most recent available data on which countries spend the largest proportion of GDP on R\&D activities. While the data predates the pandemic, it helps shine a light on how funding research can bolster economic competitiveness. Here is a summary of the top three nations in the World Bank's list. In 2018, Israel spent $4.95 \%$ of GDP on R\&D, South Korea spent $4.81 \%$ of GDP on R\&D, Switzerland spent $3.37 \%$ of GDP on R\&D ${ }^{2}$. Research and development expenditure (\% of GDP) in the neighboring countries of Armenia is shown in the table 2.

Table 2. Research and development expenditure (\% of GDP), 2018*

\begin{tabular}{|l|c|}
\hline \multicolumn{1}{|c|}{ Country } & \% of GDP \\
\hline Armenia & 0,19 \\
\hline Georgia & 0,30 \\
\hline Iran & 0,83 \\
\hline Turkey & 0,96 \\
\hline Azerbaijan & 0,18 \\
\hline
\end{tabular}

*The table was compiled by the author based on data from the World Bank

According to the table, Armenia is only $0.01 \%$ ahead of Azerbaijan in this index, but it lags far behind the other three neighboring countries.

There are a number of problems in the field of science in the Republic of Armenia, which hinder the development of the field. These problems include the low salaries of researchers, the small share of young scientists in the total number of scientists, the results of scientific research not being applied in practice, etc. The need to ensure close cooperation between the state, production, science and education participants has been discussed many times in Armenia. However, my practical experience in the field of education and science proves that this cooperation has not been formed yet. The different participants operate mainly independently of each other, as a result of which novelties are created, the demand for which is sometimes not in the market. Sometimes research on the same topic is carried out by different scientific organizations, which do not cooperate with each other, that`s why sometimes duplicate work is observed.

\footnotetext{
${ }^{1}$ Innovation in agriculture: a key process for sustainable development, San Jose, May 2014, 20p., p. 16

${ }^{2} \mathrm{https}: / /$ www.weforum.org/agenda/2020/11/countries-spending-research-development-gdp/
} 
It is widely recognized that innovation requires certain types of public sector support. In developing and emerging countries, public institutions are weaker and generate a number of failures that do not affect developed countries to the same extent. Lack of information - such as, for example, paucity of statistics on the informal sector - lack of co-ordination across agencies and lack of stable human resources reduce the ability of public institutions to play their role as efficiently as possible. Policies which are fine "in theory" might simply not work in that context: for instance, an R\&D tax credit has little sense when tax collection is at best partial. It is important that policy messages addressed to developing countries take into account the level of development of their institutions and administrative system - for their success, policies must be "resilient" to weak institutions ${ }^{1}$.

Conclusions. The innovation process comes about largely within "innovation systems" made up of organizations and private and public stakeholders interconnected in different ways and possessing the technical, commercial and financial competencies and inputs necessary for innovation. The government plays a fundamental role, supplying the economic, social and institutional conditions that foster innovation in agriculture.

For the development of innovative agriculture in Armenia, the government of RA should

$>$ create a national platform that should unite all participants in the innovative agriculture system,

$>$ develop a strategy for the development of innovative agriculture, which should be an integral part of the strategy for an innovative economy strategy,

will be posted,

$>$ create a website on innovations in agriculture, where innovations in the field of agriculture technologies.

develop state support programs aimed at conducting agricultural activities with innovative

$>$ increase the efficiency of consulting services,

$>$ increase the amount of state funding in the field of science,

$>$ take measures to involve farmers in innovative agriculture not as consumers, but as idea generators.

\section{REFERENCES}

1. FAO's work on agricultural innovation, Sowing the seeds of transformation to achieve the SDGs, FAO, 2018, 20p., p. 6

2. Innovation, Productivity and Sustainability in Food and Agriculture, Main Findings from Country Reviews and Policy Lessons, OECD Publishing, Paris, 2019, p. 85,

3. Innovation in agriculture: a key process for sustainable development, San Jose, May 2014, 20p., p. 1-2

4. Guy Faure, Yuna Chiffoleau, Frédéric Goulet, Ludovic Temple and Jean-Marc Touzard, Innovation and development in agricultural and food systems, France, 2018, p.108-110

5. Innovation in agriculture: a key process for sustainable development, San Jose, May 2014, 20p., p. 16

6. Retrieved from https://www.weforum.org/agenda/2020/11/countries-spending-research-development-gdp/

7. Innovation for Development, A DISCUSSION OF THE ISSUES AND AN OVERVIEW OF WORK OF THE OECD DIRECTORATE FOR SCIENCE, TECHNOLOGY AND INDUSTRY, OECD, May, 2012, 30 p., p. 22

\footnotetext{
${ }^{1}$ Innovation for Development, A DISCUSSION OF THE ISSUES AND AN OVERVIEW OF WORK OF THE OECD DIRECTORATE FOR SCIENCE, TECHNOLOGY AND INDUSTRY, OECD, May, 2012, 30 p., p. 22
} 